\title{
UPAYA PENINGKATAN DETEKSI BREEDING PLACE DEMAM BERDARAH DENGUE DENGAN APLIKASI BERBASIS ANDROID DI KECAMATAN IMOGIRI BANTUL YOGYAKARTA
}

\author{
Resmi Aini ${ }^{1}$, Hendra Rohman ${ }^{2}$, Rina Widiastuti ${ }^{3}$, Andhy Sulistyo ${ }^{4}$ \\ 1,2,3Politeknik Kesehatan Bhakti Setya Indonesia \\ 4Universitas Ahmad Dahlan \\ *email: hendrarohman@mail.ugm.ac.id
}

\begin{abstract}
ABSTRAK
Kejadian demam berdarah dengue di Kabupaten Bantul Yogyakarta pada tahun 2014 meningkat cukup tinggi. Desa Selopamioro, Kecamatan Imogiri, memiliki lingkungan dengan kondisi banyak air tergenang dan benda-benda yang memungkinkan air tergenang. Hal ini merupakan tempat ideal bagi perkembangan jentik nyamuk aedes aegypti. Sampah tidak dikelola dengan baik sehingga benda-benda yang menjadi perkembangbiakan jentik nyamuk (breeding place) menjadi lebih banyak. Peranan masyarakat dalam memantau dan melaporkan keberadaan jentik nyamuk hanya dipilih oleh Jumantik dengan sistem pelaporan manual sehingga tidak efektif. Pemberdayaan dan partisipasi masyarakat dalam pencegahan demam berdarah dengue dengan cara penyuluhan dan pelatihan pemantauan jentik nyamuk di daerah breeding place berbasis android. Aplikasi smartphone berbasis android dibuat untuk membantu masyarakat mengenal sekaligus membudayakan pemberantasan sarang nyamuk yang merupakan upaya paling murah dan efektif. Peranan perempuan menjadi sangat penting untuk dioptimalkan dalam kegiatan kader dimasyarakat untuk meningkatkan kesehatan masyarakat yang berpengaruh pada pembangunan manusia yang maju. Kegiatan pelatihan deteksi breeding place demam berdarah dengue dengan aplikasi berbasis android mampu memantau, mendata dan melacak lokasi keberadaan jentik nyamuk aedes aegypti di daerah breeding place, mengoptimalkan kegiatan Jumantik dan terbentuknya kader-kader baru untuk meningkatkan pengendalian vektor nyamuk dalam membudayakan gerakan Satu Rumah Satu Jumantik melalui PSN 3M Plus.
\end{abstract}

Keywords: DBD, jumantik, aplikasi android

\section{PENDAHULUAN}

Indonesia masih mengalami permasalahan kasus Demam Berdarah Dengue (DBD) dengan Kejadian Luar Biasa (KLB) dan cenderung meningkat baik dalam jumlah kasus maupun luas wilayah penyebarannya. Pada tahun 1994 seluruh propinsi di Indonesia telah terjangkit DBD dan sampai tahun 2008 tercatat lebih dari 300 kabupaten/kota telah terjangkit penyakit ini (Setiawan, Supardi, \& Bani, 2018). Daerah Istimewa Yogyakarta merupakan daerah endemis DBD menduduki peringkat ke lima secara nasional. Menurut data Dinas Kesehatan Bantul (2017) kejadian DBD pada tahun 2014 ada 622 kasus, tahun 2015 menjadi 1441 kasus dan pada tahun 2016 meningkat cukup tinggi menjadi 2442 kasus. Wabah demam berdarah masih menjadi momok ditengah 
ISSN : $2620-4665$ (print)

ISSN : 2620 - 4673 (online)

Website : http://jurnal.untan.ac.id/index.php/JPLP2KM

masyarakat. Penyakit yang timbul akibat jentik nyamuk aedes aegypti tak jarang mengakibatkan kematian. Lingkungan memegang peranan yang sangat penting dalam menyebabkan penyakitpenyakit menular. Lingkungan dengan kondisi banyak air tergenang dan benda-benda yang memungkinkan air tergenang merupakan tempat ideal bagi perkembangan jentik nyamuk aedes aegypti tersebut. Benda-benda yang menjadi perkembangbiakan jentik nyamuk yang tidak terkontrol disebut breeding place sehingga mengakibatkan jumlah nyamuk akan semakin meningkat (Widyorini, Endah Wahyuningsih, Murwani Bagian Kesehatan Lingkungan, \& Kesehatan Masyarakat, 2016). Pengendalian penyakit DBD dimana menitikberatkan pada upaya pencegahan dengan gerakan pemberantasan sarang nyamuk (PSN) selain penatalaksanaan penderita DBD dengan memperkuat kapasitas pelayanan kesehatan dan sumber daya, memperkuat surveilans epidemiologi dan optimalisasi kewaspadaan dini terhadap KLB. Manajemen pengendalian vektor secara umum diatur dalam Peraturan Menteri Kesehatan RepupKeblik Indonesia Nomor 374/MenKes/Per/III/2010 tentang Pengendalian Vektor (Kemenkes, 2010). Dalam upaya pemberantasan sarang nyamuk, pemerintah memerlukan bantuan partisipasi seluruh masyarakat. Oleh karena itu, partisipasi masyarakat dalam pemberantasan sarang nyamuk DBD tersebut perlu ditingkatkan antara lain pemeriksaan jentik nyamuk secara berkala (PJB) dan berkesinambungan serta menggerakan masyarakat dalam pemberantasan sarang nyamuk penyebab DBD (Tanjung, 2012). Pencegahan yang dapat dilakukan saat ini adalah dengan memutus rantai penularan dengan memberantas penular DBD maupun jentik nyamuknya (Wowor, 2017).

Selama ini peranan masyarakat dalam memantau dan melaporkan keberadaan jentik nyamuk hanya dipilih oleh kader-kader yang disebut Juru Pemantau Jentik Nyamuk (Jumantik) yang bertugas melaksanakan dan melaporkan pemeriksaan jentik secara berkala di rumah warga. Kegiatan pemantauan dikoordinir jumantik yang bertugas memantau jentik, mendatangi setiap rumah dan mencatat ada jentik atau tidak di kertas rekap. Hasil rekap diberikan Pusat Kesehatan Masyarakat (Puskesmas). Proses ini sangat tidak efisien dan memakan waktu. Tugas kader-kader Jumantik yang memiliki kelemahan yaitu tidak semua warga dilibatkan dalam pemantauan jentik nyamuk, dibutuhkan dana yang besar bagi Jumantik dan bentuk pelaporan hasil pemeriksaan jentik yang diberikan kepada puskesmas selalu tidak tepat waktu sehingga pelaporan membutuhkan waktu yang lama serta data tentang keberadaan jentik nyamuk dirumah warga sering hilang (Agustini, 2015). 
Pemantauan jentik-jentik nyamuk di rumah warga seringkali tidak terlaksana sesuai dengan peraturan Menteri Kesehatan Republik Indonesia sehingga dibutuhkan sistem informasi dan teknologi yang cepat dan akurat yang akan meningkatkan produktivitas agar data pemantauan dapat tercatat dengan baik dan dapat dilihat daerah mana yang kurang aktif dalam kegiatan ini dan daerah mana yang berbahaya serta harus dilakukan tindakan lebih lanjut yang lebih serius.

Sistem informasi dan teknologi yang sering digunakan dengan memanfaatkan smartphone berbasis android hanya sebatas komunikasi padahal hampir sebagian besar masyarakat menggunakannya dan sampai saat ini belum dimanfaatkan sebagai aplikasi dalam mendata dan melaporkan pemeriksaan jentik nyamuk berkala. Keterlibatan warga untuk menggunakan aplikasi smartphone berbasis android untuk menginformasikan kepada otoritas kesehatan tentang lokasi perkembangbiakan breeding place menggunakan formulir interaktif dan media sosial. Kemajuan smartphone dengan berbasis android dan cakupan internet yang lebih baik, sistem aplikasi ini mampu melacak breeding place sehingga bisa lebih cepat didata.

Aplikasi smartphone berbasis android yang dibuat untuk membantu masyarakat mengenal sekaligus membudayakan PSN yang merupakan upaya paling murah dan efektif dalam mencegah penyakit DBD. Sehingga masyarakat yang sebelumnya tidak peduli dengan bahayanya jentik jadi lebih peduli, aware, rajin lagi bersihkan lingkungan sekitar.

Kegiatan pemantauan jentik-jentik nyamuk sering diadakan warga untuk menekan penyebaran demam berdarah. Selama ini kegiatan pemantauan dikoordinir oleh warga setiap minggu. Warga yang bertugas memantau jentik mendatangi setiap rumah dan mencatat ada jentik atau tidak di kertas rekap. Hasil rekap diberikan ke RT, setiap RT memberikan rekap ke RW dan setiap RW memberikan rekap ke kelurahan. Proses ini sangat tidak efisien dan memakan waktu. Maka dibutuhkan sistem yang mengifisienkan proses ini secara online. Hasil rekap dapat dilihat secara langsung oleh RT, RW dan kelurahan saat warga mengisi data jentik. Pelaku sistem dapat mengakses melalui web di PC maupun di perangkat mobile secara online. Objek lokasi berada di Kedung Jati, RT 05 Selopamioro. Imogiri, Bantul Yogyakarta. Hasilnya diharapkan dapat mengefisienkan proses pendataan rekap jentik-jentik nyamuk dan mempermudah pelaku sistem mendapatkan data rekap jentik-jentik nyamuk.

Peranan perempuan menjadi sangat penting untuk dioptimalkan dalam kegiatan kader di masyarakat untuk meningkatkan kesehatan masyarakat yang berpengaruh pada pembangunan manusia yang maju. Secara tradisional perempuan menjadi pemain utama dalam menjaga rumah 
ISSN : $2620-4665$ (print)

ISSN : 2620 - 4673 (online)

Website : http://jurnal.untan.ac.id/index.php/JPLP2KM

dan lingkungannya sehingga apabila perempuan tidak mempunyai pengetahuan yang cukup dan melakukan aktifitas yang berhubungan dengan penyakit dengue dengan baik, maka program pencegahan demam berdarah terutama dalam PSN tidak tercapai. perempuan memiliki peran yang sangat besar dalam mentransfer pengetahuan kesehatan kepada masyarakat. Interaksi sosial yang melekat di masyarakat memungkinkan terjadinya transfer informasi diantara internal para kader maupun antara kader dengan warga, terutama ibu-ibu dan balita.

Perguruan tinggi dapat menjadi fasilitator dalam mengatasi masalah tersebut. Transfer ilmu pengetahuan dan teknologi dapat diupayakan dengan menjalin kerjasama kemitraan melalui promosi kesehatan di Dasawisma atau pertemuan warga di Kedung Jati, RT 05 Selopamioro, Imogiri, Bantul Yogyakarta permasalahan khusus yang dihadapi oleh mitra adalah kasus DBD setiap tahunnya selalu meningkat bahkan sampai saat ini tidak semua warga dilibatkan dalam PSN. Kegiatan pemantauan jentik nyamuk hanya dilakukan oleh Jumantik yang bertugas memantau jentik nyamuk dengan mendatangi setiap rumah dan mencatat ada jentik atau tidak di kertas rekap. Proses ini sangat tidak efisien dan memakan waktu yang lama, hal ini bertentangan dengan kejadian penyakit DBD yang harus cepat ditangani. Belum pernah dilakukan pelatihan terutama bagi jumantik dengan teknologi aplikasi smartphone berbasis android yang mampu memantau, mendata dan melacak lokasi keberadaan jentik nyamuk aedes aegypti di daerah breeding place. Melihat kenyataan ini, maka perlu dibangun sebuah program pelatihan atau aplikasi yang dapat membantu dalam pendataan pemantauan jentik nyamuk.

Tujuan dari pengabdian kepada masyarakat ini diantaranya mengoptimalkan kegiatan Jumantik dilokasi mitra melalui pemantauan jentik nyamuk di daerah breeding place dengan aplikasi smartphone berbasis android dan terbentuknya kader-kader baru yang nantinya dapat meningkatkan pengendalian vektor nyamuk dalam membudayakan gerakan Satu Rumah Satu Jumantik melalui PSN 3M Plus.

\section{METODE}

Metode kerja untuk mendukung realisasi program PKM yaitu:

\section{a. Sosialisasi program PKM}

Sosialisasi program dilakukan untuk mengenalkan program dan tim kepada masyarakat. Sosialisasi diberikan kepada kelompok masyarakat di wilayah mitra, yaitu Kedung Jati, RT 05 Selopamioro, Imogiri, Bantul, Yogyakarta sasarannya adalah perempuan atau ibu- 
ibu rumah tangga yang mau mengikuti penyuluhan dan pelatihan. Dalam tahapan ini sekaligus disepakati tentang komitmen untuk melaksanakan program PKM.

b. Penyuluhan peningkatan kesadaran dalam kegiatan Pemberantasan Sarang Nyamuk (PSN)

Program ini bertujuan untuk meningkatkan pemahaman, pengetahuan dan keterampilan dalam mekanisme PSN, untuk mendapatkan hasil yang optimal, maka Jumantik harus dibentuk mulai dari setiap rumah dengan menunjuk salah satu anggota keluarga sebagai Jumantik (Gerakan 1 Rumah 1 Jumantik), sehingga penyakit DBD dapat dicegah dan dikendalikan. Masalah ini akan didekati dengan memotivasi warga dengan melakukan penyuluhan tentang dampak lingkungan yang tidak sehat akan meningkatnya kasus DBD, mengontrol sarang-sarang nyamuk di sekitar rumah mitra yang menjadi tempat berkembangbiaknya nyamuk terutama di daerah breeding place. Pada penyuluhan ini dibicarakan pentingnya membicarakan $\mathrm{DBD}$, antara lain bahayanya dapat menyerang semua orang, bagaimana cara pencegahannya.

c. Pelatihan teknik pemantauan jentik nyamuk di daerah breeding place berbasis android dengan aplikasi smartphone

Pelatihan ini bertujuan agar masyarakat dapat menggunakan aplikasi smartphone berbasis android yang mampu memantau, mendata dan melacak lokasi keberadaan jentik nyamuk aedes aegypti di daerah breeding place. Data yang diperoleh secara online dapat ditampilkan di Google Maps dan memberi informasi kasus DBD secara cepat melalui situs web dan smartphone. Pada pelatihan ini digunakan diagram alir (flow chart). Diagram alir (flow chart) ini digunakan untuk membantu analisis untuk memecahkan masalah. Diagram alir (flow chart) merupakan gambaran secara grafik yang terdiri dari simbol-simbol yang menyatakan urutan dari kegiatan yang dijalani dalam kegiatan ini.

Program dilakukan monitoring dan evaluasi dengan cara kualitatif untuk mengukur peningkatan pengetahuan, sikap, perilaku, dan keberhasilan program. Partisipasi mitra dalam pelaksanaan program partisipasi mitra dalam pelaksanaan program adalah sebagai partisipan aktif pemberdayaan masyarakat dalam upaya pencegahan melalui Gerakan 1 Rumah 1 Jumantik dalam PSN, dalam program ini tugas dan tanggung jawab mitra adalah mitra (kelompok masyarakat) menyediakan tempat untuk pelatihan, mitra mengikuti seluruh 
ISSN : $2620-4665$ (print)

ISSN : 2620 - 4673 (online)

Website : http://jurnal.untan.ac.id/index.php/JPLP2KM

rangkaian penyuluhan dan pelatihan yang diselenggarakan pengusul, mitra memanfaatkan dan menerapkan ilmu yang diperoleh selama pelatihan, mitra secara berkesinambungan memanfaatkan sistem aplikasi smartphone berbasis android, mitra menyebarluaskan informasi dan pengetahuan kepada kelompok masyarakat yang lain.

\section{HASIL DAN PEMBAHASAN}

Desa Selopamioro merupakan bagian dari Kecamatan Imogiri Kabupaten Bantul, Yogyakarta dengan jumlah penduduk 16.403 jiwa yang didominasi oleh perempuan sebanyak 8.697 jiwa, jika dilihat jumlahnya maka jumlah perempuan lebih banyak dibandingkan dengan lakilaki. Mata pencaharian warga yang paling dominan adalah petani 2.871 orang dan peternak adalah 6.864 orang. Jika dilihat jumlahnya maka mata pencaharian lebih banyak peternak. Sebagian besar penduduk di wilayah ini mempunyai usaha budidaya ikan lele dan ikan tawar sehingga banyak ditemui kolam ikan yang kosong dan selokan-selokan kecil untuk mengalirkan air dari kolam saat pengurasan, sehingga saat musim hujan tiba menjadi tempat penampungan air yang disukai oleh nyamuk aedes aegepty.

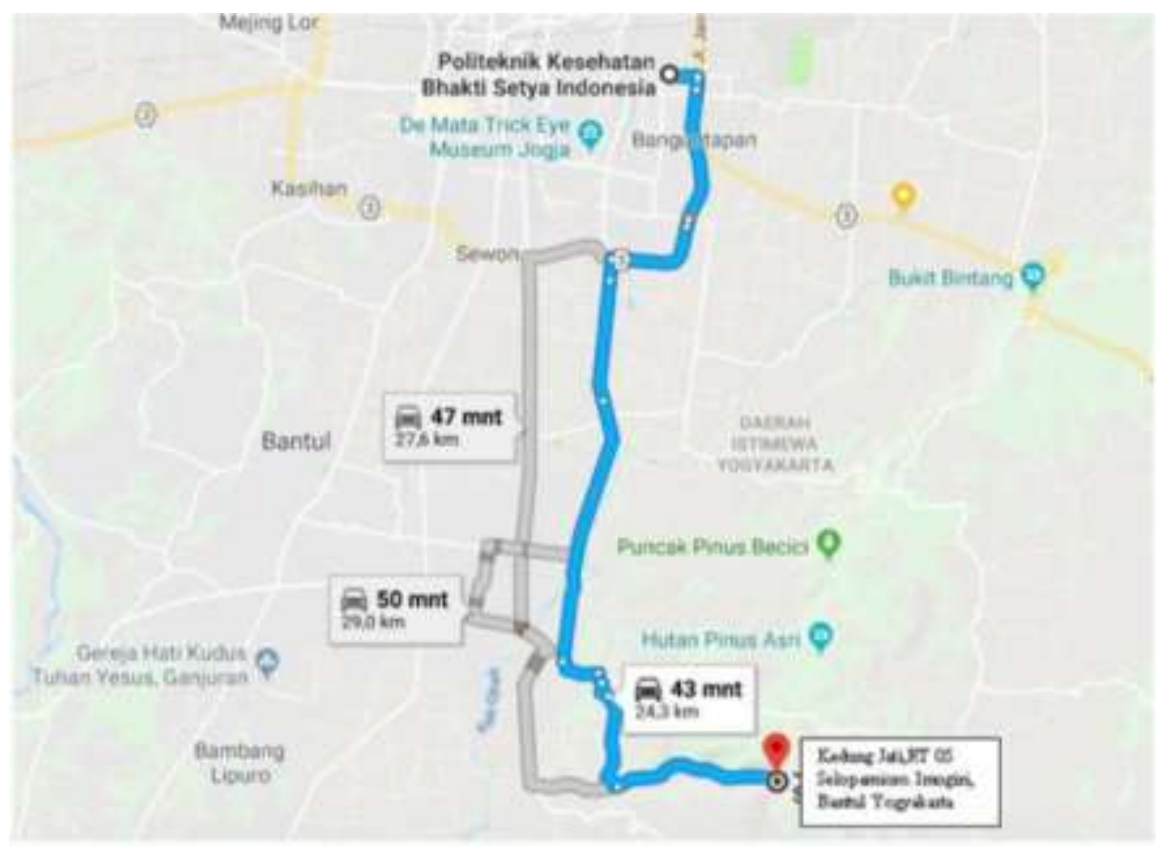




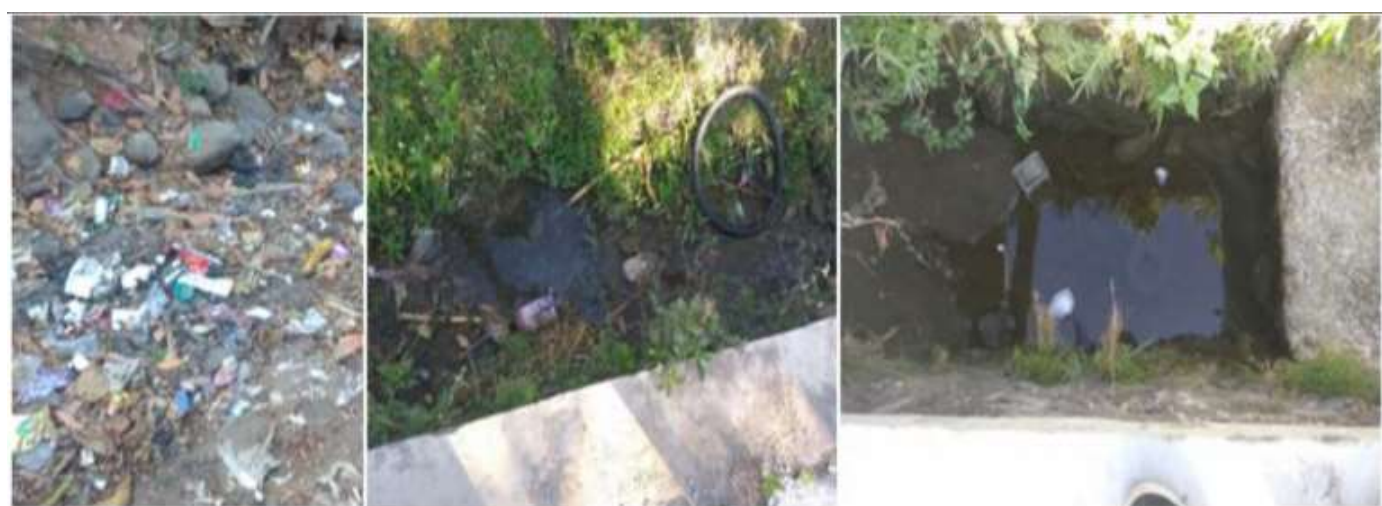

Gambar 1. Lokasi mitra Kedung Jati, RT 05 Selopamioro, Imogiri, Bantul, Yogyakarta

Menurut data monografi Desa Selopamioro jumlah penduduk miskin sebanyak 6.632 jiwa dengan 1.658 kepala keluarga. Kemiskinan merupakan salah satu faktor risiko kejadian DBD karena mengakibatkan orang tidak mampu untuk menyediakan rumah yang layak dan sehat, pasokan air minum, dan pembuangan sampah yang benar. Di lain pihak, DBD juga bisa menyerang penduduk yang lebih makmur terutama yang biasa bepergian. Masyarakat Desa Selopamioro lebih banyak membuang sampah rumah tangga yang ditampung di depan rumah dan jika sudah banyak dibakar sehingga belum ada pengelolaan sampah dengan benar. Hal ini akan mempermudah perkembangbiakan nyamuk terutama pada saat musim hujan. Benda-benda yang menjadi perkembangbiakan jentik nyamuk yang tidak terkontrol (breeding place) menjadi lebih banyak.

Ada hubungan antara breeding place $(p=0,001)$ dan ada hubungan antara perilaku masyarakat $(p=0,022)$ dengan keberadaan jentik vektor DBD (Sari, 2012). Terdapat hubungan bermakna antara perilaku PSN 3M Plus terhadap kejadian DBD (Priesley, Reza, \& Rusjdi, 2018).

Breeding place seperti sampah dan barang bekas yang dapat menampung air hujan seperti kaleng bekas, botol, plastik dan ban bekas dapat dimanfaatkan kembali melalui langkah $3 \mathrm{R}$, yaitu reduce, reuse, recycle. Tempurung kelapa serta buah-buahan berkulit keras yang berpotensi sebagai tempat genangan air juga harus dihilangkan. 
ISSN : $2620-4665$ (print)

ISSN : $2620-4673$ (online)

Website : http://jurnal.untan.ac.id/index.php/JPLP2KM

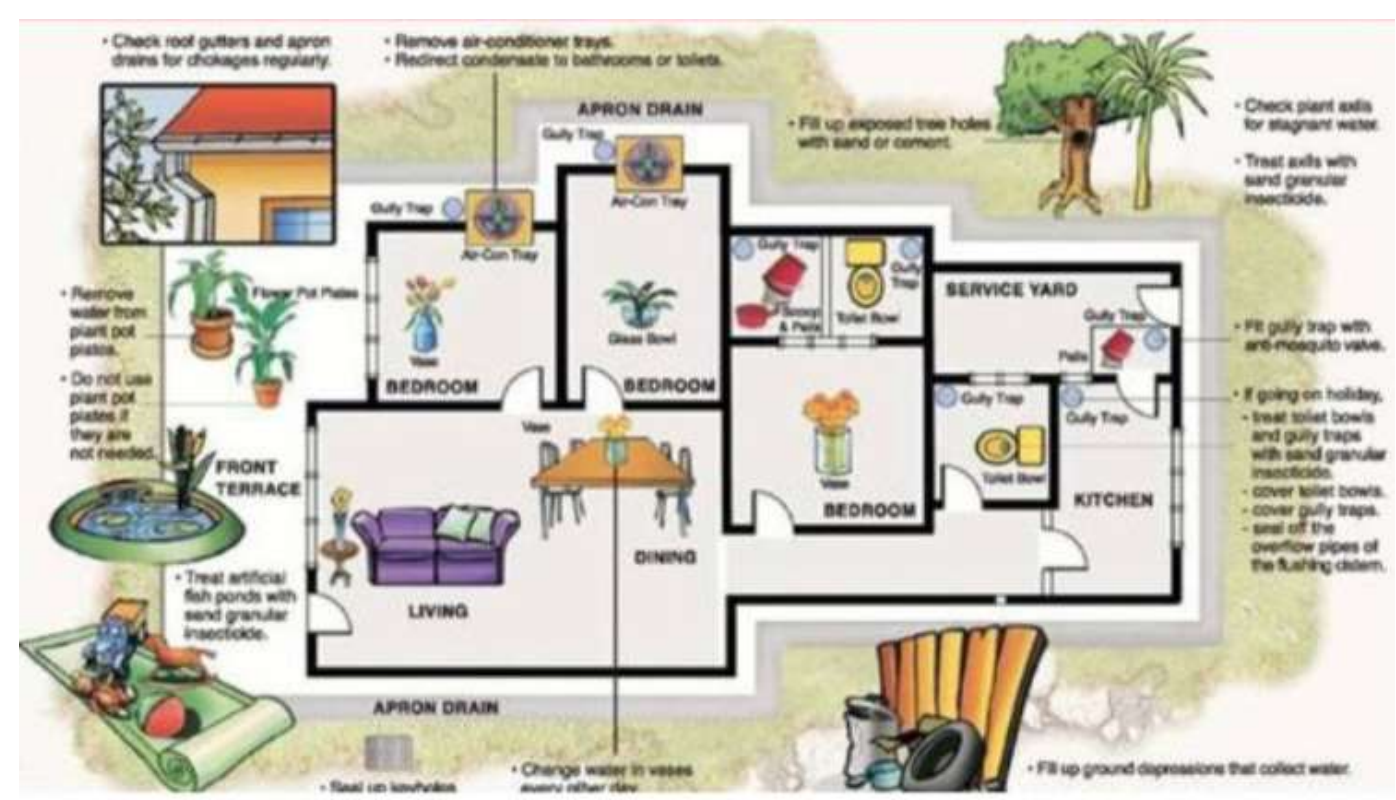

Gambar 2. Contoh tempat jentik nyamuk aedes aegypti di daerah breeding place

Ada hubungan keberadaan jentik berdasarkan jenis kontainer $(p=0,024)$ dan penutup kontainer $(p=0,042)$. Sedangkan variabel yang tidak berhubungan adalah bahan, warna dan volume kontainer. Instansi terkait memberikan penyuluhan kepada masyarakat tentang penyakit DBD dan karakteristik kontainer apa saja yang disenangi oleh nyamuk aedes $s p$, seperti jenis kontainer yang disertai penutup kontainer. Bekerja sama dengan pihak setempat, seperti memberikan pelatihan modifikasi tempat penampungan air yang dilengkapi penutup, sehingga dapat digunakan masyarakat untuk mengurangi populasi jentik nyamuk tersebut (Arfan, 2019).

Pada tahun 2016 kasus DBD di Kecamatan Imogiri ada 127 kasus sedangkan di Desa Selopamioro dilaporkan sebanyak 16 kasus. Jika dibandingkan dengan desa yang berdekatan lain seperti Desa Kebonagung dan Karangtengah maka kasus DBD Selopamioro cukup tinggi. Setiap wabah penyakit DBD menyebar, tak sedikit yang akhirnya meninggal. Sebenarnya keadaan tersebut telah menjadi perhatian pemerintah. Salah satu andalan dinas kesehatan dalam pemberantasan DBD adalah fogging. Padahal pengasapan yang berlebihan saat ini justru tidak berfungsi efektif lantaran telah terjadi mutasi gen sehingga menyebabkan nyamuk aedes aegepty menjadi makin kebal terhadap fogging. Akibatnya, jumlah kasus demam berdarah tiap tahun selalu saja meningkat. penduduk yang menjadi korban penyakit DBD justru didominasi oleh anak-anak dari kalangan miskin. Ada juga korban dari kelas atas yang turut terserang namun masih sedikit.

Model pengendalian DBD berdasarkan faktor iklim terdiri dari pengendalian pada sumber penyakit yaitu pencarian kasus DBD pada sumber penyakit secara aktif dan penyelidikan 
epidemiologi oleh petugas surveilans DBD. Pengendalian pada media penularan atau transmisi tentang manajemen lingkungan dan pengendalian vektornya, baik secara biologis, komia pada fase larva hingga dewasa. Pengendalian proses pajanan atau kontak pada masyarakat, yaitu perlindungan individu dari kontak atau gigitan nyamuk penular DBD, serta partisipasi masyarakat dalam pengendalian vektor seperti 3 M Plus, PSN hingga menjadi Jumantik (Fidayanto et al., 2013).

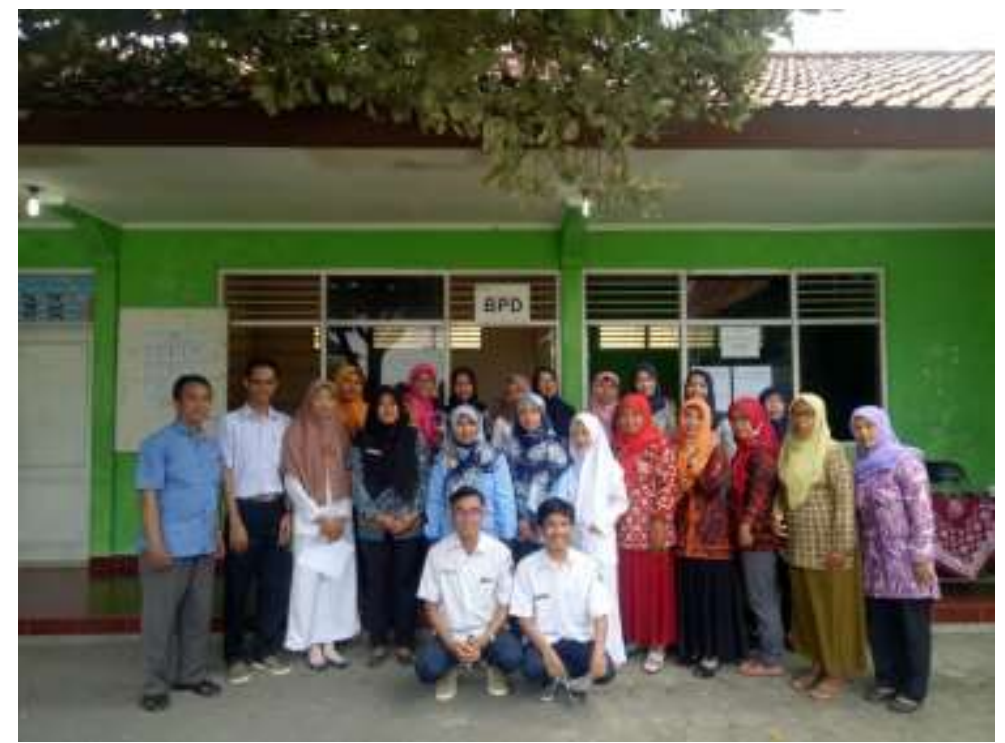

Gambar 3. Tim PKM dan peserta kader Jumantik

Desa Selopamioro memiliki 30 orang yang berperan sebagai kader PKK dan hanya sebagian yang ditunjuk sebagai Kader Jumantik. Sistem pemantauan dan pendataan jentik-jentik nyamuk di Kelurahan Selopamioro, Imogiri, Bantul, Yogyakarta yang terlaksana selama ini adalah dengan cara manual. Para kader-kader yang membantu dengan suka rela keliling rumah warga dan memeriksa keberadaan jentik-jentik nyamuk di tempat-tempat tertentu. Hasil pemantauan tersebut dicatat dalam selembar kertas, yang akan direkap di RT, dari seluruh RT akan dilaporkan ke RW, dan dari seluruh RW akan dilaporkan ke kelurahan. Seringkali yang terjadi adalah datadata pemantauan tersebut tidak semua tersampaikan ke kelurahan, dan tidak sedikit pula datadata yang hilang. Sehingga hasil laporan tidak sesuai dengan kenyataan yang sesungguhnya. Faktor lain yang sering terjadi adalah ada beberapa RT yang kurang aktif dalam kegiatan seperti ini. Pemantauan jentik-jentik nyamuk di rumah warga seringkali tidak terlaksana. Padahal bukan tidak mungkin daerah-daerah tersebut terdapat jentik-jentik nyamuk yang membahayakan. Hal ini bertentangan dengan Peraturan Menteri Kesehatan Republik Indonesia Nomor 
ISSN : $2620-4665$ (print)

ISSN : 2620 - 4673 (online)

Website : http://jurnal.untan.ac.id/index.php/JPLP2KM

374/MenKes/Per/III/2010 tentang Pengendalian Vektor yang menitikberatkan kepada masyarakat dalam membudayakan gerakan Satu Rumah Satu Jumantik melalui PSN 3M Plus.

Sistem informasi dan teknologi yang sering digunakan masyarakat dengan memanfaatkan aplikasi smartphone berbasis android hanya sebatas komunikasi padahal hampir sebagian besar warga terutama Jumantik menggunakannya dan sampai saat ini belum dimanfaatkan sebagai aplikasi dalam mendata dan melaporkan pemeriksaan jentik nyamuk berkala. Kemampuan media sosial yang memungkinkan pengguna untuk berpartisipasi dan berbagi informasi sejauh ini kurang dimanfaatkan di ruang kesehatan global.

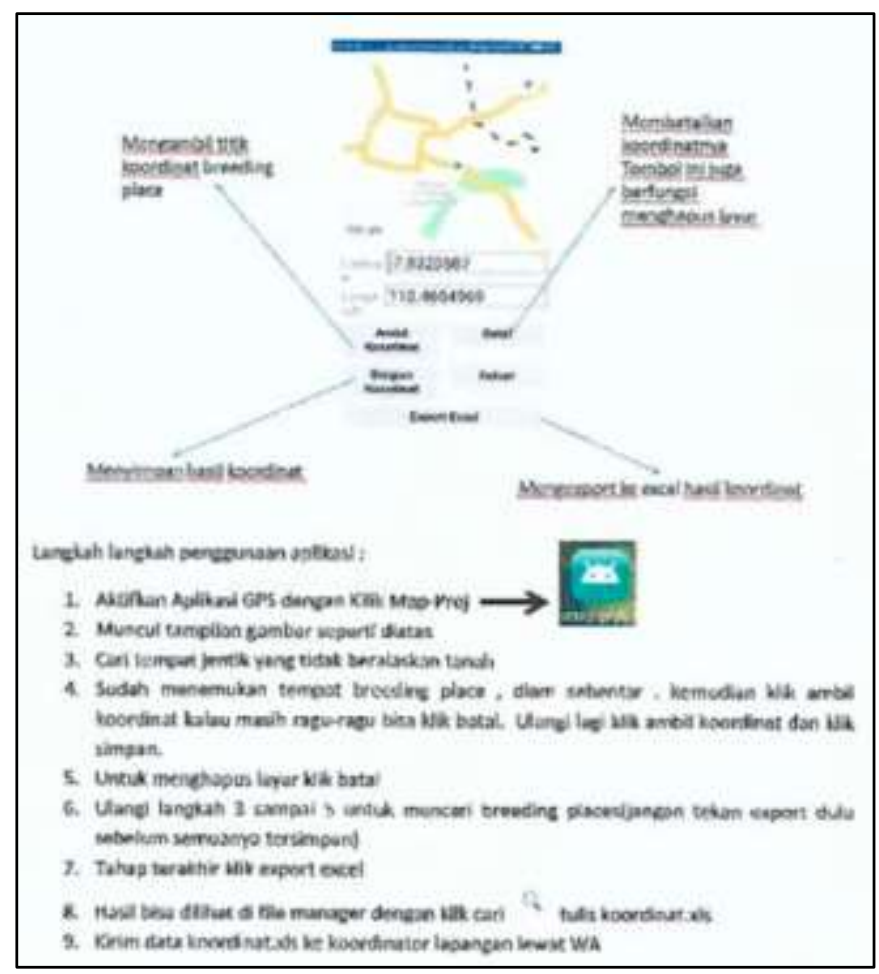

Gambar 4. Petunjuk penggunaan aplikasi Jumantik berbasis android

Pelatihan aplikasi smartphone berbasis android untuk memantau dan melacak lokasi keberadaan jentik nyamuk. Persiapan yang dilakukan yaitu:

a. Alat yang digunakan dalam pelatihan ini adalah handphone android dengan spesifikasi ROM 8 GB, berkamera minimal 8 MB dan RAM 4 GB, komputer atau laptop dengan processor 12 atau di atasnya, hard disk dengan kapasitas 750 GB, RAM 4 GB dan server.

b. Sistem operasi android, windows 8, MySQL, PHP kriteria dalam pelatihan ini adalah warga setempat yang mempunyai pengetahuan tentang jentik nyamuk di daerah breeding place 
dan mempunyai handphone dengan spesifikasi android, RAM minimal $4 \mathrm{~GB}$, memori internal $32 \mathrm{~GB}$, dan berkamera depan minimal 8 MP.

c. Pengguna admin atau operator adalah tim PKM yang bertugas untuk melakukan pengolahan data yang didapatkan dari responden yang memantau jentik nyamuk di daerah breeding place dan juga data semua responden. Pengguna admin memiliki hak dalam manajemen sistem monitoring ini dan memantau aliran dan perubahan data yang terjadi pada sistem.

d. Desain, hasil dari analisis sistem, aplikasi berbasis android ini dirancang dengan pemodelan unified modelling language (UML) sehingga dapat mempermudah dalam penerapan sistem. Hasil UML ini menghasilkan rancang database, alur program dan aktifitas yang dilakukan saat sebuah operasi dieksekusi dan memodelkan hasil dari aktifitas tersebut.

e. Coding, menerjemahkan persyaratan logika dari pseudocode atau diagram alur ke dalam suatu bahasa pemrograman baik huruf, angka, dan simbol yang membentuk program. Java adalah bahasa pemrograman yang digunakan untuk development android. XML dipakai di webservice, konfigurasi, layout dan berbagai keperluan lain.

f. Pengujian, sebelum program diimplementasikan, maka program harus bebas dari kesalahan. Kesalahan program yang mungkin terjadi antara lain karena kesalahan penulisan (coding), kesalahan proses, atau kesalahan logika.

g. Implementasi, implementasi sistem merupakan tahap meletakan sistem sehingga siap untuk dioperasikan. Implementasi bertujuan untuk mengkonfirmasi modul-modul perancangan, sehingga pengguna dapat memberi masukan kepada pengembangan sistem selanjutanya.

h. Pemeliharaan sistem adalah suatu kombinasi dari berbagai tindakan yang dilakukan untuk menjaga suatu sistem dalam, atau memperbaikinya sampai, suatu kondisi yang bisa diterima. 
ISSN : $2620-4665$ (print)

ISSN : 2620 - 4673 (online)

Website : http://jurnal.untan.ac.id/index.php/JPLP2KM

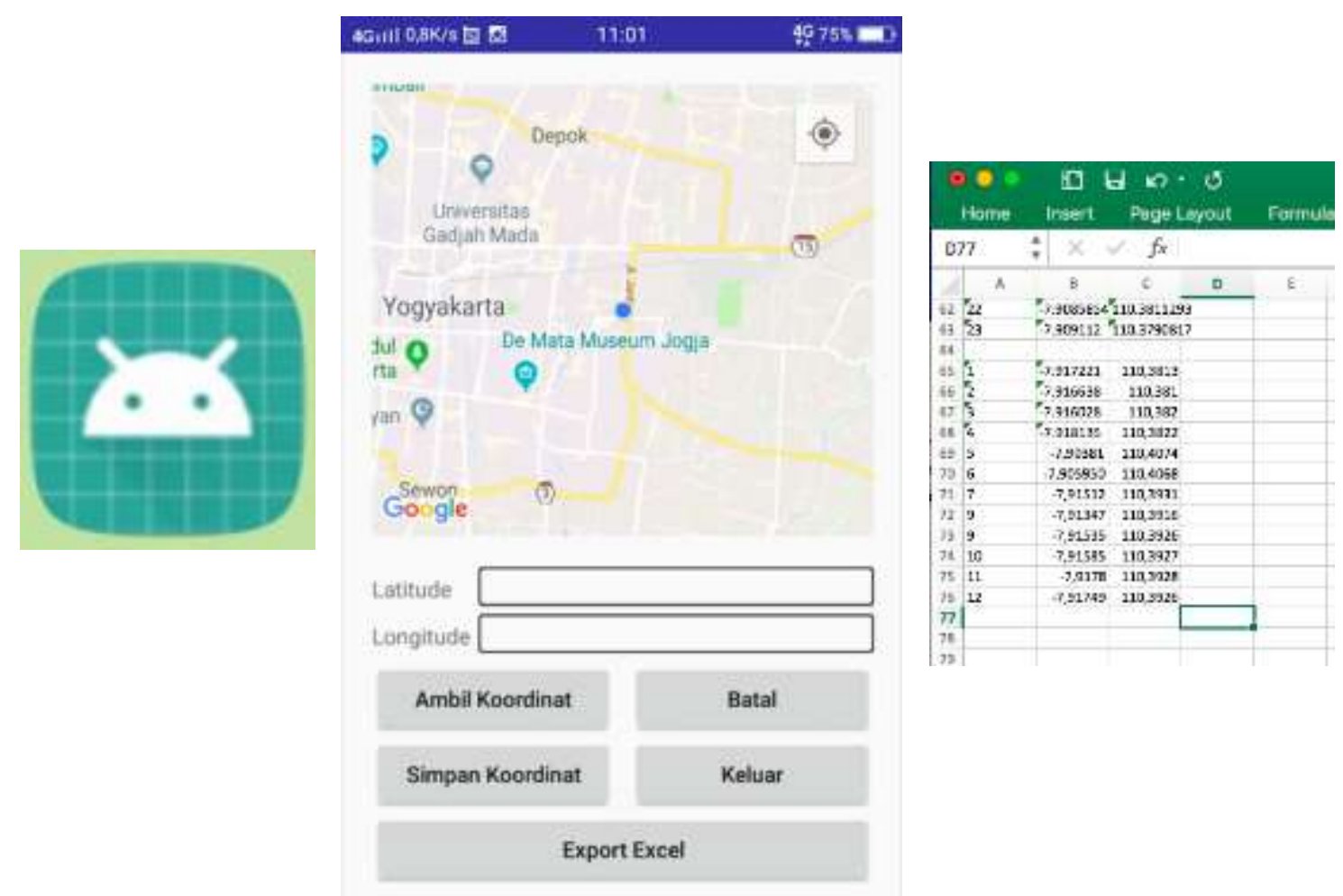

Gambar 5. Tampilan icon, aplikasi Jumantik berbasis android dan hasil format excel

Aplikasi Jumantik berbasis android menampilkan menu yang sederhana agar mudah digunakan oleh semua kader Jumantik. Pada aplikasi tersebut menampilkan peta lokasi keberadaan titik koordinat, dimana pada saat memilih tompol ambil koordinat maka akan muncul titik koordinat latitude dan longitude. Tombol batal untuk membatalkan atau menghapus titik koordinat yang telah diambil pada layar peta sebelumnya. Tombol simpan koordinat untuk menyimpan koordinat dan tombol keluar untuk keluar aplikasi Jumantik. Pada tombol export excel, digunakan untuk melakukan pemindahan data ke format excel dan akan tersimpan di media penyimpanan handphone.

Sistem informasi pencegahan dan edukasi masyarakat dalam penanganan endemik penyakit menular dan tidak menular berbasis web untuk peningkatan kesehatan masyarakat dapat mengumpulkan, mengelola, dan memvisualisasikan data dan informasi dalam bentuk web pada masyarakat tentang pengetahuan penyakit menular dan tidak menular (mengedukasi) penyebab, cara penularan dan cara pencegahannya serta pemetaan lokasi puskesmas (Tri Agus Setiawan, Agus llyas, 2018). 

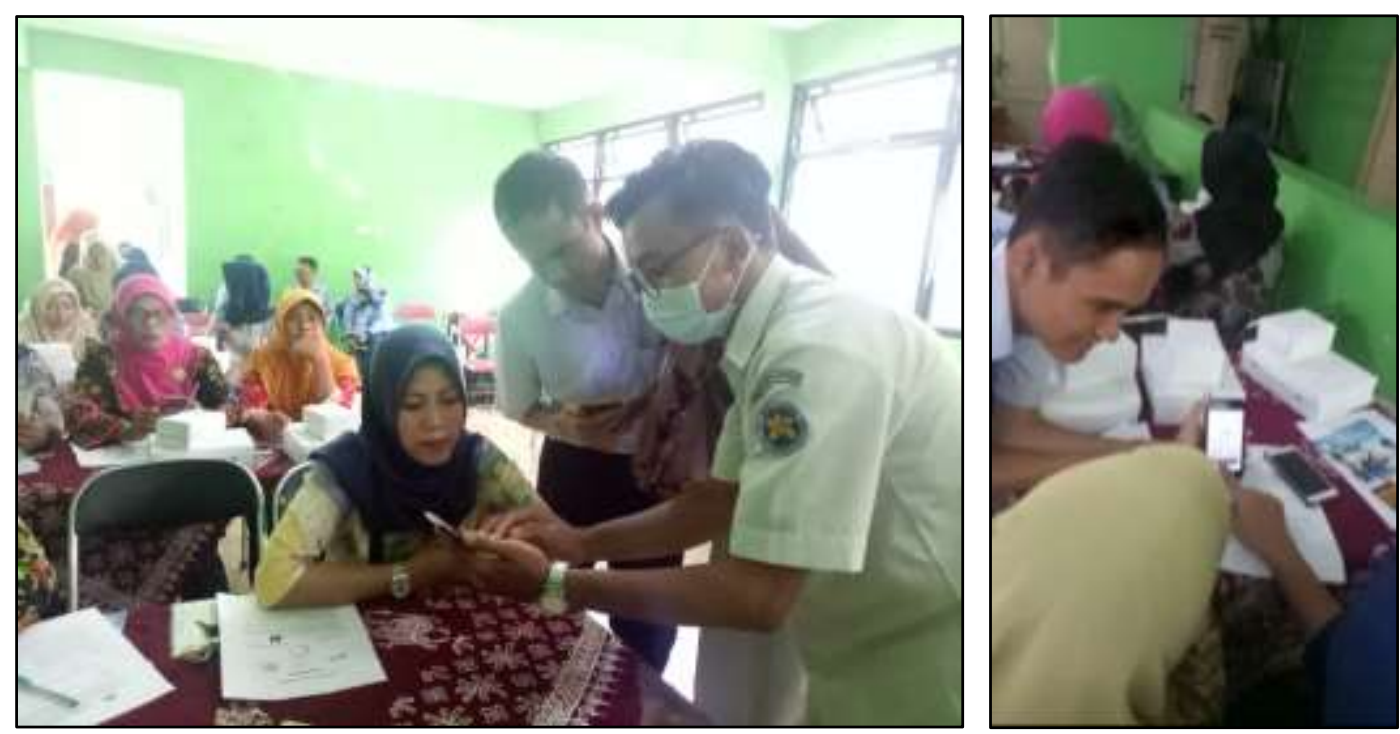

Gambar 6. Pelatihan penggunaan aplikasi kepada kader Jumantik

Pada kegiatan pelatihan penggunaan aplikasi kepada kader Jumantik, dimulai kegiatan instalasi aplikasi Jumantik satu persatu pada handphone masing-masing kader Jumantik. Pada kegiatan ini dapat berjalan dengan lancar. Kegiatan cara penggunaan aplikasi Jumantik juga dilakukan satu persatu karena kader Jumantik menggunakan jenis handphone android yang beragam. Permasalahan yang ditemukan yaitu beberapa setting GPS pada handphone kader Jumantik belum aktif, sehingga posisi titik pada peta tidak muncul. Kegiatan dilanjutkan dengan pengambilan titik koordinat breeding place dengan berkeliling di sekitar lingkungan lokasi pelatihan dengan membagi ke dalam empat kelompok kader Jumantik. Masing-masing kelompok mengirimkan hasil titik koordinat breeding place ke kordinator Tim PKM. Setelah data titik koordinat didapatkan, kader Jumantik melakukan export ke dalam format excel, pada kegiatan ini, beberapa kader Jumantik mengalami kebingungan dalam mencari file data yang tersimpan. Setelah Tim PKM melakukan check satu persatu, beberapa permasalahan yang ditemukan adalah letak media penyimpanan di handphone kader Jumantik yang berbeda-beda dan belum terinstalasi aplikasi yang mampu membaca data dalam format excel. Tim PKM menginstal aplikasi office dan melakukan pencarian file pada media penyimpanan masing-masing kader Jumantik, sehingga data koordinat breeding place dapat terbaca. 
ISSN : $2620-4665$ (print)

ISSN : $2620-4673$ (online)

Website : http://jurnal.untan.ac.id/index.php/JPLP2KM

\section{KESIMPULAN}

Kegiatan pelatihan deteksi breeding place demam berdarah dengue dengan aplikasi berbasis android di Kecamatan Imogiri Bantul Yogyakarta mampu memantau, mendata dan melacak lokasi keberadaan jentik nyamuk aedes aegypti di daerah breeding place, mengoptimalkan kegiatan Jumantik dan terbentuknya kader-kader baru untuk meningkatkan pengendalian vektor nyamuk dalam membudayakan gerakan Satu Rumah Satu Jumantik melalui PSN 3M Plus.

\section{UCAPAN TERIMA KASIH (ACKNOWLEDGEMENTS)}

Ristekdikti yang telah memberikan Hibah Program Kemitraan Masyarakat (PKM) tahun 2019, Desa Selopamioro Kecamatan Imogiri Kabupaten Bantul Yogyakarta sebagai mitra dalam kegiatan PKM, mahasiswa Prodi D3 Rekam Medis dan Informasi Kesehatan, D3 Teknologi Tranfusi Darah dan D3 Farmasi yang telah membantu dalam kegiatan PKM.

\section{DAFTAR PUSTAKA}

Agustini, R. T. (2015). Periodic Larva Inspection Evaluation in Tanah Kalikedinding Public Health Center. Journal Promkes, 3(2), 195-205.

Arfan, I. (2019). Keberadaan Jentik Aedes Sp Berdasarkan Karakteristik Kontainer Di Daerah Endemis Dan Non Endemis Demam Berdarah Dengue. Jurnal IImiah IImu Kesehatan: Wawasan Kesehatan, 5(2), 258-266. https://doi.org/10.33485/jik-wk.v5i2.140

Fidayanto, R., Susanto, H., Yohanan, A., Yudhastuti, R., Astra, P. T., Lestari, A., .. Malang, H. (2013). Control Model of Dengue Hemorrhagic Fever. Jurnal Kesehatan Masyarakat Nasional, 7(11), 522-528.

Kemenkes. (2010). Permenkes RI No. 374/Menkes/Per/II/2010 tentang Pengendalian Vektor.

Priesley, F., Reza, M., \& Rusjdi, S. R. (2018). Hubungan Perilaku Pemberantasan Sarang Nyamuk dengan Menutup, Menguras dan Mendaur Ulang Plus (PSN M Plus) Terhadap Kejadian Demam Berdarah Dengue (DBD) di Kelurahan Andalas. Jurnal .Fk.Unand.Ac.Id, 7(1), 1-07.

Sari, D. (2012). Hubungan Breeding Place Dan Perilaku Masyarakat Dengan Keberadaan Jentik Vektor DBD Di Desa Gagak Sipat Kecamatan Ngemplak Kabupaten Boyolali. Program Studi Kesehatan Masyarakat Fakultas IImu Kesehatan Universitas Muhammadiyah Surakarta, 32. 
Setiawan, B., Supardi, F., \& Bani, V. K. B. (2018). Analisis Spasial Kerentanan Wilayah Terhadap Kejadian Demam Berdarah Dengue di Wilayah Kerja Puskesmas Umbulharjo Kota Yogyakarta Tahun 2013. Jurnal Vektor Penyakit, 11(2), 77-87. https://doi.org/10.22435/vektorp.v11i2.6464.

Tanjung, M. O. (2012). Marista Octaviani Tanjung Alumnus Fakultas Kesehatan Masyarakat UNDIP @ 2012 Page 1. 1(1), 1-8.

Tri Agus Setiawan, Agus llyas, A. P. W. (2018). Pencegahan Dan Edukasi Masyarakat Dalam Penanganan Endemik Penyakit Berbasis Web Untuk Peningkatan Kesehatan Masyarakat Di Kota Pekalongan. Jurnal Litbang Kota Pekalongan, 15.

Widyorini, P., Endah Wahyuningsih, N., Murwani Bagian Kesehatan Lingkungan, R., \& Kesehatan Masyarakat, F. (2016). Faktor Keberadaan Breeding Place Dengan Kejadian Demam Berdarah Dengue Di Semarang. Jurnal Kesehatan Masyarakat, 4, 2356-3346.

Wowor, R. (2017). Pengaruh kesehatan lingkungan terhadap perubahan epidemiologi demam berdarah di Indonesia. Jurnal E-Clinic, 5(2), 105-113. 